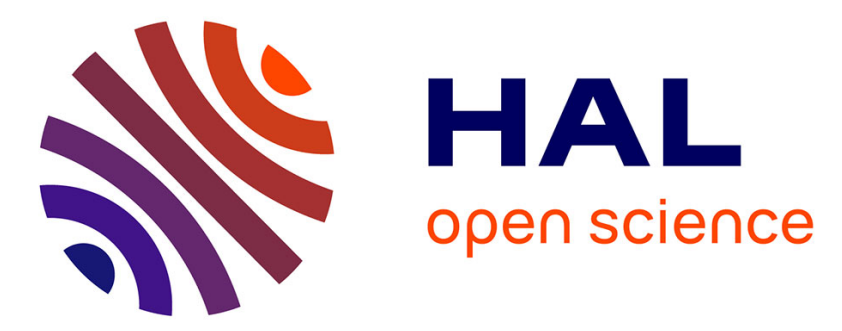

\title{
Mapping the Argentine New Left: Social Liberation, National Liberation and Revolutionary Violence
}

David Copello, Casa de Velázquez

\section{To cite this version:}

David Copello, Casa de Velázquez. Mapping the Argentine New Left: Social Liberation, National Liberation and Revolutionary Violence. 2020. hal-02525133

\section{HAL Id: hal-02525133 \\ https://hal.science/hal-02525133}

Preprint submitted on 30 Mar 2020

HAL is a multi-disciplinary open access archive for the deposit and dissemination of scientific research documents, whether they are published or not. The documents may come from teaching and research institutions in France or abroad, or from public or private research centers.
L'archive ouverte pluridisciplinaire HAL, est destinée au dépôt et à la diffusion de documents scientifiques de niveau recherche, publiés ou non, émanant des établissements d'enseignement et de recherche français ou étrangers, des laboratoires publics ou privés. 


\section{Mapping the Argentine New Left: Social Liberation, National Liberation and}

Revolutionary Violence, 1969-1977

Latin American Perspectives (forthcoming)

David Copello, Casa de Velázquez

Calle de Paul Guinard, 3 - 28040 Madrid

david.copello@casadevelazquez.org 


\title{
Mapping the Argentine New Left: Social Liberation, National Liberation and Revolutionary Violence, 1969-1977
}

\begin{abstract}
In recent years, investigation on 1960s/1970s revolutionary activism in Argentina has led to the publication of multiple case studies. Building on this existing literature, the article provides a more general view of what is often called the "New Left", which is first characterized by the importance assigned to three issues: social liberation, national liberation and revolutionary violence. The paper then isolates two differentiating lines within this political space: an ideological divide (Marxism vs. Peronism) and an instrumental division over the strategic status of violence (insurrection vs. protracted people's war vs. politicalmilitary action). In the conclusion, we provide a summarized graphic representation to facilitate comparative reflections on radical politics in the long sixties. This overview shall help non-specialists familiarize with a complex historical reality that has become key to contemporary political debates on memory and human rights in Argentina.
\end{abstract}

Keywords: New Left; Argentina; Revolutionary Peronism; Revolutionary Left; Guerrilla. 


\section{Introduction}

In the 1960s and 1970s, Argentina experienced an unprecedented wave of political unrest (Anzorena, 1998, De Riz, 2000, Novaro \& Palermo, 2003, Franco, 2012). After the urban insurrection of Córdoba in 1969 (often nicknamed Cordobazo), a series of armed revolutionary organizations emerged in the public space. They deeply affected Argentine politics, up until 1977 when they were physically annihilated by a civil-military dictatorship established a year earlier (Gillespie, 1982, Carnovale, 2011). These revolutionary movements have become a major element in Argentine contemporary political debates, marked by regular controversies over the 1970s "guerrilla": oversimplified and/or anachronistic accounts of recent history are a common component of Argentine political competition. Meanwhile, academic contributions have privileged case-study approaches rather than theoretical synthesis, making it harder for the public to grasp the main issues of revolutionary action in the 1960s and 1970s. This article thus aims at providing a general frame to understand the complex dynamics at stake among political activists involved in radical protest during that period. It discusses some of the concepts used to describe that cycle of mobilization, with a special focus on the "New Left", for which it provides a synthetic definition based on the existing literature.

From a global perspective, the "New Left" refers to a wave of radical movements that emerged in the "long sixties"(Marwick, 1998) or "1968 years" (Dreyfus-Armand et al., 2000). They criticized the traditional Left focus on economic exploitation and denounced a broader process of alienation in capitalist and bureaucratic systems (Gosse, 2005, Keucheyan, 2012). In Latin America, "there was a tendency to define the left not so much by the goal it was pursuing [i.e. socialism] but by the means it used to reach that goal" (Harnecker, 2015): armed struggle or institutional struggle. What is usually referred to as "New Left" in the region is the combined appeal for socialism and armed struggle. However, the idea of a "New 
Left" entails a very heterogeneous political reality, whose limits are hard to draw, and whose form and content vary from one country to another.

Although Argentina clearly appears as a major actor in the consolidation of a transnational New Left political culture in Latin America (Marchesi, 2017), there have been strong discussions on the correctness of the New Left label in Argentine scholarship on radical politics. Indeed, some strong peculiarities affect Argentina's political structure of cleavages - notably the impact of Peronism on the blurring of ideologies. Studies on radical Peronist organizations have seldom used the New Left frame, and have rather privileged the concept of "Revolutionary Peronism" (Bozza, 2001). This may seem logical, as a large proportion of progressive Peronists (aspiring to a "socialist homeland") do not identify as part of the Left-sometimes associated with anti-nationalism and intellectual elitism. However, interactions between revolutionary Peronists and Left-wing organizations, intellectuals and activists were permanent (Altamirano, 2011), forming a universe of common references that is key to understanding Argentine politics of that period. It will hence be argued that the concept of "New Left" can be a useful and heuristic (although imperfect) tool to explore revolutionary unrest in Argentina in the 1960s and 1970s.

The article shows the label is useful to explore Argentine politics between 1969 (Cordobazo) and 1977 (annihilation of revolutionary organizations on Argentine soil). It provides a simple definition of it based on previous research and proposes a graphic model to guide non-specialists into the Argentine New Left.

\section{Three Defining Features}

Scholars and activists have used several conceptual frames to study the 1960s/1970s Argentine revolutionary wave, but none of them has reached general approval. This section 
first gives a definition of the "New Left" based on three criteria; to assess its heuristics, it then discusses the relevance of the "revolutionary Left" alternative framework.

First, we can define the Argentine New Left by its belief in an immediate horizon of social liberation, directly connected to the influence of the Cuban Revolution. The seizing of power by Fidel Castro in Havana in 1959 was an important milestone for the Latin-American Left as a whole: it questioned the reformist tactics privileged by socialists and communists in the context of post-1956 East/West Peaceful Coexistence. On the contrary, the favorable results obtained by guerrilla warfare in Cuba seemed to show that a direct revolutionary strategy was possible for Latin American countries, although this heavily contradicted the Kremlin's instructions. Hence, through the Cuban example, social liberation (i.e. the creation of a socialist society) was reaffirmed as an immediate aspiration in Latin America. In Argentina, this led to a serious dispute inside traditional Socialist and Communist Parties, resulting in a series of splits and the emergence of a pro-Cuban current in the early 1960s (Tortti, 2009).

A second feature of the Argentine New Left is the relationship to Peronism and to the idea of national liberation. Named after Juan Domingo Perón (Argentine president, 19461955), Peronism blurred the distinction between Left and Right politics, by advocating a strong form of nationalism and, at the same time, developing social policies directed towards the working classes. Peronism thus covers a wide specter of the Argentine political landscape, ranging from pro-fascist to pro-Castroist sectors, and including trends of conservative populism or progressive welfare-state reformism. Multiple disputes over Peronism took place inside the traditional socialist and communist Left. In the 1950s, Socialist and Communist Parties had taken a clear anti-Peronist stance, in the name of antitotalitarianism or anti-fascism, despite grassroots popular support for Perón. A characteristic of the New Left was to reassess the "revolutionary potentialities of Peronism" (Tortti, 1999: 
213). Indeed, considering that Peronism had reached high levels of support within the working classes, some sectors broke up with the Socialist and Communist Parties, advocating for the peronization of the Left so as to reconnect with its original social base. A distinctive feature of the New Left is hence: 1) to consider that the political culture of the Left must be reassessed to account for the Peronist fact; 2) to favor ideological and practical encounters with Peronists around a set of common objectives. This evolution can also be connected to the global move towards decolonization in the post-war period, mainly in Africa and Asia, and to the diffusion of the economic theory of dependency (Ferraro, 2008). These converging influences fostered pre-existing anti-imperialist tendencies, the denunciation of Argentina's "semi-colonial" status under US domination, and the search for a new political independence (or national liberation). Within the Argentine Left, this anticolonial school of thought paved the way to an increased dialogue with Peronism, which had always taken a strong stance against imperialism in the name of the Third Position, "neither Yankee nor Marxist" (Zanatta \& Aguas, 2005). These ideological interactions between Left-wing and Peronist antiimperialism thus promoted national liberation as a shared fundamental stake for the New Left.

The use of violence as a legitimate revolutionary tool, which skyrocketed after 1969, is a third defining element of the Argentine New Left. This must be connected to the influence of the Cuban revolution and anti-colonial wars, in Algeria and Vietnam in particular. Among scholars, there is no agreement on the importance of violence to characterize the New Left. In their founding essay, Hilb and Lutzky equated the New Left with "armed struggle, as immediate practice or as near future and, most of all, as a desired goal", and with the idea that "war [is] the only way to make politics" (Hilb \& Lutzky, 1984: 8, 29). More recent research has challenged this view, criticizing its reduction of the New Left to armed organizations: to take a broader perspective, Oberti and Pittaluga have even suggested talking about "New 
Lefts" in plural (Oberti \& Pittaluga, 2011). There is no straightforward conclusion to be taken from this discussion. It nevertheless shows that, for the New Left, violence is always a debatable issue, involving different (and sometimes opposing) replies and strategies around a shared concern. Violence itself took multiple forms, and was often combined with electoral or institutional participation (see below). It could even be perceived as a tool to defend human rights or as a path towards democracy—despite a frequent (but not systematic) rejection of liberal institutions (Copello, 2019a, 2019b). One of the challenges here is to classify these relations to violence in a mobile ideological and organizational landscape.

Choosing the "New Left" frame does not entail denying the various problems it might carry, nor does it suppose rejecting alternative conceptualizations. It aims, however, at identifying a series of political dynamics that would be invisible otherwise, when using classifying labels such as "Revolutionary Left" for instance. This last concept is useful to avoid overstating the Old/New division. Indeed, important sectors of the New Left came from the old communist and Trotskyist Left, their evolution being the result of organizational and ideological splits occurred along the 1950s and 1960s. The impact of this provenience on the modeling of individual trajectories should not be underestimated. Moreover, the distinction between Old and New Left is not always obvious: several Trotskyist groups had changing tactics and objectives along the analyzed period. They sometimes bridged the gap between Marxism and nationalism in the name of anti-imperialism, and sometimes advocated for an orthodox form of class-struggle internationalism instead (Coggiola, 2006). Nevertheless, the distinction between Old and New Left (problematic as it is) has been an object of inquiry and public debate with real political effects, and has impacted on the way political actors themselves have conceived of their behavior. There is a difference between the 1960s/1970s revolutionary wave and earlier forms of revolutionary activism, and it should not go unnoticed because of possible confusions. 
However imperfect, the concept of "Argentine New Left" thus brings a heuristic perspective on radical mobilizations of the 1960s and 1970s. It conveys the image of a political playground, on which actors coming from different political traditions can position themselves along shared issues. Although insufficient, it is hence useful to understand subjective dimensions of political cleavages in the 1968 years. Three main defining features have been extracted from the literature: social liberation, national liberation and armed struggle. To be part of the Argentine New Left, one must invest these three issues with a subjective meaning, and consider them key to the political moment. Their interpretation and combination will, however, vary along ideological and instrumental lines.

\section{Ideological Cleavage}

The main ideological cleavage inside the Argentine New Left opposed Peronism and Marxism. Peronists relied on a multiclass alliance to promote national sovereignty, while Marxists aimed at establishing socialism under the primacy of the working-class. However, this principal contradiction was multiform, open to hybridization and fluctuations: multiple groups presenting diverse combinations of Peronism and Marxism coexisted in the space of the Argentine New Left. Figure 1 shows a simplified graphic understanding of these dynamics. In this section, we present the main features of the organizational Peronist/Marxist divide, then highlight several ways through which it was distorted, and finally explain how this resulted in intermediate articulations of Peronism and Marxism. 
Figure 1: Ideological Cleavage of the Argentine New Left

\section{<FIGURE 1>}

Legend: JP Lealtad splits from Montoneros to adopt a more movementist stance towards Peronism. ERP 22 splits from PRT-ERP to adopt a more populist stance, closer to Peronism. ERP Fracción Roja splits from PRTERP to adopt a more classist stance. The FAR merge with Montoneros.

\section{Marxism/Peronism: the Principal Contradiction}

Two major organizations epitomized the New Left's main contradiction: Montoneros for Peronism and the Partido Revolucionario de los Trabajadores-Ejército Revolucionario del Pueblo (Workers' Revolutionary Party_People's Revolutionary Army, PRT-ERP) for Marxism.

Montoneros (Gillespie, 2008, Bartoletti, 2010a) was created at the end of the 1960s by a few dozens of activists, mainly based in Buenos Aires and Córdoba (Lanusse, 2005). Its starting action, operación Pindapoy, took place in May 1970, one year after the Cordobazo. It consisted in the kidnapping and assassination of one of the main symbols of anti-Peronism, general Aramburu - leader of the military coup against Perón in 1955. In the years following Operación Pindapoy, Montoneros gained popularity and absorbed other armed groups: a section of the Fuerzas Armadas Peronistas (Peronist Armed Forces, FAP) (Luvecce, 1993, Duhalde \& Pérez, 2001, Stavale, 2012), the small organization Descamisados (Campos, 2012), and above all the Fuerzas Armadas Revolucionarias (Revolutionary Armed Forces, FAR) (González Canosa, 2012). Between 1970 and 1973, Montoneros activists put together many acts of armed propaganda, mainly bombings on symbolic targets. They also set up extortive kidnappings to finance these operations, and attacked police or military facilities to steal weapons. The global aim of these activities was not to seize power through armed 
struggle, but to pressure the military regime of the moment, and facilitate Perón's return from Spain (where he lived in exile). In 1973, Montoneros lent its full support to Héctor Campora, the Peronist candidate in the presidential polls called by the decaying military administration. After the electoral victory, Montoneros placed a few sympathizers in governmental teams and in parliament. The organization also diversified its activities. Special activist groups were created in secondary schools (Garaño \& Pertot, 2002, Manzano, 2011), universities (Chama \& González Canosa, 2011, Rodríguez, 2014), and slums (Camelli, 2011, Snitcofsky, 2014). A youth territorial extension (Robles, 2014) and a female branch (Grammático, 2011) were also launched. Between 1973 and 1974, these front organizations (as opposed to the clandestine apparatus of Montoneros itself) put together multiple street demonstrations with massive attendance (Gillespie, 2008: 194-195). According to most reasonable estimates, Montoneros had no more than 1,500 to 2,500 permanent armed combatants (Central Intelligence Agency, 1977), but it surely gathered tens of thousands of sympathizers at the peak of its activism. However, after Perón himself replaced President Cámpora in October 1973, the government operated a political U-turn to the far right, displacing Montoneros from power centers. After the death of Perón in May 1974, Montoneros and all its front organizations went underground and took armed actions up again, this time against the Peronist government led by Perón's widow, María Estela “Isabelita” Martínez de Perón (Gillespie, 2008: 249). Although Montoneros' explicit new objective became the creation of a popular army in preparation for integral war, its operations still basically resorted to actions of urban guerrilla: extortive kidnappings, bombings or raids on police stations and garrisons. Nevertheless, the military capabilities of the organization skyrocketed, and it started encouraging indiscriminate murder of soldiers and policemen. Interestingly, and although Montoneros entered in direct conflict with the Peronist administration, it maintained its affiliation to Peronism. Its members tried to account for the sudden volte-face of Perón by the manipulation of his entourage. This 
conspiracy theory enabled Montoneros to claim its Peronist authenticity and loyalty in the face of Perón himself (Salas, 2007). Hence Montoneros remained the main organization in the Peronist pole of the Argentine New Left.

At the other end of this ideological specter, the Marxist pole of the Argentine New Left was dominated by the Partido Revolucionario de los Trabajadores (PRT) (Pozzi, 2004, Rubenstein, 2005, Carnovale, 2011). This organization appeared in 1963, after the merging of a Trotskyist party headed by Nahuel Moreno, Palabra Obrera, and of the Frente Revolucionario Indoamericanista Popular (Popular Indo-Americanist Revolutionary Front, FRIP) led by Mario Roberto Santucho. The PRT, composed of a few hundred activists, operated a fusion of Marxism and anti-imperialist indigenism. In 1968, internal tensions eventually resulted in a split between PRT-La Verdad (The Truth), led by Moreno, and PRTEl Combatiente (The Combatant), led by Santucho. The latter advocated armed struggle as a strategy to reach power, and created a parallel military structure in 1970: the Ejército Revolucionario del Pueblo (ERP). Party and army coexisted within the same organization, usually called PRT-ERP. In the main, it concentrated its armed operations in the urban sector but, unlike Montoneros, it also projected to settle a rural guerrilla in the short-term. During the 1973 elections, the PRT-ERP appealed for a blank vote. After the victory of Peronism, the organization declared it would not undertake actions against the new authorities if they did not suppress revolutionary activism. However, it maintained an overtly aggressive posture towards the armed forces, considered as enemies of the people, and created a rural guerrilla foco in the province of Tucumán (in the north of Argentina) in 1974. From then on, there was an increased militarization of activism, and decreasing debate on political orientations among adherents. Following the example of the Vietnamese liberation process, a strategic turn towards protracted people's war was undertaken. However, after the direct intervention of the army in "law enforcement" from February 1975, the PRT-ERP rural foco was totally 
dismantled, and the organization progressively declined. Although uncertain, the number of its active members has been estimated between 2,500 and 6,000 at its peak, in 1975 (Carnovale, 2011: 15). From a strictly quantitative point of view, it was the major revolutionary armed force on Argentine soil.

\section{An Impure Cleavage}

The above presentation creates an impression of purity, but both Montoneros and the PRTERP welcomed activists with very diverse origins. These imported some of their ideological preferences that, in turn, were integrated and reformulated in several ways, altering fixed conceptions of Marxism and Peronism.

The impact of post-conciliar Catholicism on founders of Montoneros, for instance, was crucial. In the 1960s, leaders such as Mario Firmenich or Roberto Perdía started out as devout Christians involved in the Acción Católica (Celesia \& Waisberg, 2010). There, they met with Third-Worldist priests such as Carlos Mugica (Martín, 1992, Magne, 2004, Touris, 2012) and discovered reviews like Cristianismo y Revolución (Morello, 2003). In their case, religion paved the way towards Peronism (Donatello, 2010). More generally, the impact of Catholicism has been commonly mentioned to account for the prevalence of traditional gender norms among revolutionary organizations (Cosse, 2017), although these were often challenged in the practice of activism (Andújar, D’Antonio, \& Gil Lozano, 2009).

As for the PRT-ERP, the coherence of its doctrinal attachment to Marxism can be discussed, given its strong theoretical fluidity. One of its foundational nucleuses originally advocated a generic form of anti-imperialism, only later converted to Marxist theses. The connection to Trotskyism is ambivalent as well. Although the initial fusion with Nahuel Moreno's group helped building ties with the Fourth International (preserved up until 1973), 
this affiliation relied on tactics rather than conviction. According to Jérémy Rubenstein, the PRT-ERP's rapprochement with Trotskyism aimed at raising international support, the final objective being the constitution of "a new Guevara-inspired International” involving Chinese, Albanese, Cuban and Vietnamese communist parties (Rubenstein, 2005: 46-48). The ideological and strategic identification with Marxism thus expressed itself through a hybrid form, associating Guevarism with the examples of Vietnamese national liberation struggles and Maoism. Moreover, this ideological stance turned out to be very fluid: in 1973, the organization broke up with the Fourth International and got closer to the Third International controlled by the Soviet Union (Weisz, 2004: 22-25). The PRT-ERP had reached a hegemonic position in the Marxist pole of the Argentine New Left, but the contours of its Marxism were extremely hazy.

Nationalism was also an influential motif both for the PRT-ERP and Montoneros, as exemplified by the Movimiento Nacionalista Tacuara (Tacuara Nationalist Movement, MNR), a far-right nationalist, anti-communist and anti-Semitic organization (Gutman, 2003). In 1962, a group of activists influenced by Peronism and Marxism left the MNR and created the Movimiento Nacionalista Revolucionario Tacuara (Tacuara Revolutionary Nationalist Movement, MNRT). Among its founding members were José Luis Nell, who later joined Montoneros (Tarcus, 2007: 458), and Joe Baxter, who later became a member of the PRTERP (Tarcus, 2007: 52-54). There were thus paths from far-right nationalism to both Peronism and Marxism, or at least towards the syncretic forms of Peronism and Marxism proposed by Montoneros and the PRT-ERP.

Considering the intense circulation of actors and ideas inside this complex organizational landscape, it can be argued that, beyond the space of the Argentine New Left, there existed a larger "organizational nebula of activism" that connected very different ideological traditions (Cucchetti, 2013: 36). This nebula reflected a generalized phenomenon 
of political radicalization, exceeding traditional political cleavages and characteristic of the 1960s and 1970s. That phenomenon can also be connected to other impacting crossorganizational issues of the period, such as youth politicization and counterculture (Manzano, 2014). The New Left made no exception in this syncretic kaleidoscope, and its main ideological poles (Peronism and Marxism) must be seen as landmarks rather than stable anchor points.

\section{Multiple Articulations of Peronism and Marxism}

Apart from Montoneros and the PRT-ERP, many organizations appeared on the New Left during the same period, some gathering a fistful of activists, others recruiting hundreds of partisans - precise membership figures are usually difficult to determine for such clandestine organizations. They offered diverse ideological combinations of Peronism and Marxism, as shown in Figure 1.

The highest position on the axis corresponds to "movementist" Peronists. For them, what must prevail is respect for Perón's leadership, which implies a pacific coexistence with the whole Peronist movement, including its most reactionary sectors. The Juventud Peronista Lealtad (Peronist Youth Loyalty, JP Lealtad), ensued after a split inside Montoneros in 1973 (Garategaray, 2012, Pozzoni, 2013) embodied this position. Peronism opposed this movementist sector to an "alternativist" sector, represented by organizations such as the Fuerzas Armadas Peronistas - Comando Nacional (Peronist Armed Forces — National Command, a remainder of the original FAP that did not merge with Montoneros) and the associated Peronismo de Base (Luvecce, 1993, Duhalde \& Pérez, 2001, Stavale, 2012), which Daniel James deemed "true" revolutionary Peronists — unlike Montoneros (James, 1976). These activists saw a conflict inside Peronism, opposing a bourgeois board and a working- 
class base (whose interests had to be defended). Although alternative Peronists fought for the return of Perón until 1973, they also produced a systematic criticism of his leadership. The Peronist pole of the Argentine New Left was thus divided according to two opposing "gravitational" forces: movementism (that drove Peronism away from Marxism) and alternativism (that brought it closer to Marxism) — Montoneros being equidistant.

At the other end of the axis, Argentine New Leftists divided according to two symmetric "gravitational forces": classism and populism. The lowest position on the axis corresponds to classism, which gathered organizations clearly privileging social liberation over national liberation, more firmly opposed to Peronism and focused on the autonomous activism of the working-class. Classism was opposed by populists who, despite being Marxists, put an emphasis on national liberation against imperialism and admitted collaboration with some sectors of the bourgeoisie. Among classist organizations, some argue the Organización Comunista Poder Obrero (Workers’ Power Communist Organization, OCPO), with several hundred activists, was Argentina's third biggest revolutionary organization (Castro \& Iturburu, 2004, Cormick, 2015). OCPO gave priority to anticapitalism over national liberation, even though the issue of anti-imperialism was part of its discursive repertoire. The Fracción Roja (Red Fraction) of the PRT-ERP also lied at a similar level on the populist/classist axis. This organization was the result of a split occurred in 1972-1973, when the PRT-ERP gave up on Trotskyism as well as on the Fourth International, and increasingly emphasized nationalist dimensions of its discourse (Cormick, 2012). On the contrary, ERP Fracción Roja reaffirmed its affiliation to Trotskyism and its radical rejection of Peronism. OCPO and ERP Fracción Roja thus embodied the classist fringe within the Marxist pole of the New Left. At the other end of the Marxist specter was the Ejército Revolucionario del Pueblo 22 de Agosto (August 22 ${ }^{\text {nd }}$ People's Revolutionary Army, ERP 22), also created in 1972-1973 after another division inside the PRT-ERP. 
Against the call to cast a blank vote formulated by the majoritarian sector of the PRT-ERP in 1973, ERP 22 gave its support to the Peronist candidate in the presidential election (Weisz, 2005). This organization created a review, Liberación por la Patria Socialista, whose collaborators included figures from Peronismo de Base and FAP — Comando Nacional. It can here be seen that, between Marxist populist fringes and Peronist alternativist fringes, individuals circulated easily thanks to a set of common references, notably articulated around Cuba. Occasionally, this closeness even led to attempts of ideological and organizational fusion, as shown by the aborted discussions between ERP 22 and FAP-Comando Nacional (Weisz, 2005: 37-38).

Further, multiple kinds of mobility were possible between these opposing poles, also allowing for non-linear trajectories. One could indeed move through poles by "skipping" one or several of the previously presented positions. This happened to the Fuerzas Armadas Revolucionarias (FAR), whose founding members had left the Communist Party in the 1960s to adopt Guevarist views, but quickly moved closer to Peronism. This led to the merging of FAR and Montoneros, officially announced in 1973 (González Canosa, 2012). The FAR's evolution shows that there existed combinations of Marxism with movementist Peronism, stepping over intermediate stages such as alternativist Peronism. We must therefore take the linear division of Marxism and Peronism cautiously: ideological fluctuations can follow very diverse tracks. However, the very existence of these complex fluctuations between Peronism and Marxism shows that the Argentine New Left was indeed a relatively autonomous space, allowing for internal mobility and exchanges between separate poles.

\section{Instrumental Cleavage}


The rejection of "pacifism" - understood as "peaceful coexistence" with capitalism - is one of the New Left's major characteristics. However, New Left politics are not restricted to warfare strategies (Hilb \& Lutzky, 1984), nor to the only influence of Régis Debray’s (Debray, 1967) Guevara-inspired theory of foquismo ${ }^{1}$ (Terán, 2004). As stated by Aldo Marchesi, the New Left's political culture "was not merely the result of preformed ideas or ideologies. Rather, it resulted from the interaction of previously held ideas and the political circumstances that [...] activists had to face" (Marchesi, 2019: 187). If violence and armed struggle were indeed central issues, the rejection of pacifism led to multiple conceptions of revolutionary action, irreducible to warfare or foquismo. Figure 2 displays diverse positions on this issue, with three strategic points of reference: insurrection (left); protracted people's war (right); mixed conceptions (by far the more frequent) regarding "political-military" action (center). 
Figure 2: Instrumental Cleavage of the Argentine New Left

\section{$<$ FIGURE 2>}

Legend: The PCR and VC take an insurrectionist stance on the use of violence. Montoneros, originally a political-military organization (PMO), later evolves towards people's war strategy.

\section{Insurrectional Strategies}

Despite rejecting the pacifist discourse of communist parties, supporters of insurrection also rejected guerrilla warfare. They conceived revolution as the outcome of a massive urban uprising, following long-term militant action fostering class consciousness among the working classes, in labor unions in particular. Armed struggle shall only intervene when the uprising has reached its terminal phase: the masses take over the revolutionary movement and create an armed wing (with restricted and subordinate tasks), consisting in self-organized militias or sleeper cells of the revolutionary party. The historical reference for insurrection was the October Revolution in 1917 Russia (Lissandrello, 2013).

The armed road to socialism is certainly a major trait of the Argentine New Left, but it did not entail reproducing Cuba's foquista model in every circumstance, as shown by the insurrectional tradition. Foquismo's use of violence aims at creating the subjective conditions (consciousness and will) to spark the light of revolution, without waiting for socialism's objective (socio-economic) preconditions. Conversely, the insurrectional model only brings about violence when the revolutionary process is already engaged and meets the requirements (objective and subjective) of its success. Likewise, while foquismo favors the constitution of a rural army, insurrectional strategy rests upon the rallying of the urban proletariat. This preference can be deemed quite logic in the Argentine context, where a vast majority of the population lived in urban areas. 
Besides, in the late 1960s, a series of foquista setbacks stimulated the insurrectional option: the death of Che Guevara in Bolivia in 1967; the tragic outcome of rural guerrilla attempts in Argentina in the 1960s (Duhalde \& Pérez, 2001, Salas, 2006a); the urban uprising of Córdoba in 1969. This event especially reinforced the insurrectionist conviction that, against foquistas' beliefs, an urban self-organized insurrection led by workers and students in city centers was best suited to provoke a regime crisis (Lissandrello, 2013). In this context, insurrection appeared to some as a more efficient revolutionary strategy for Argentina than guerrilla warfare.

In organizational terms, Maoist and Trotskyist groups were the main supporters of this strategy. The Partido Comunista Revolucionario (Revolutionary Communist Party, PCR) and Vanguardia Comunista (Communist Vanguard, VC) for instance, two pro-Chinese organizations resulting (respectively) from splits in the Communist and Socialist Parties in the 1960s, adhered to insurrection (Campione, 2008, Lissandrello, 2013, Celentano, 2014). The PRT also responded to this model up until 1968, when the division between PRT-El Combatiente (at the root of the ERP) and PRT — La Verdad (that maintained the insurrectional line of action) took place (Campione, 2008, Mangiantini, 2014).

\section{Protracted People's War}

Partisans of protracted people's war (also called integral war) usually took the Chinese and Vietnamese revolutions for models, rather than Cuba. Their strategy relied on the progressive construction of a popular army, based on a mixed urban and rural web. It was meant to become a regular army, able to defeat state-loyal forces militarily in the ultimate stage of the revolution (Zedong, 1954, Nguyên Giáp, 1962). Taking this logic to its extreme, the triumph 
of revolution would rely on military conditions exclusively. Unarmed activism in labor unions or universities becomes either superfluous or subordinate.

Protracted people's war shares one common characteristic with foquismo: the idea that, in a situation where the objective (socio-economic) conditions of socialism are not given, armed struggle can create its subjective conditions. However, both strategies diverge in the importance they pay to rural action. In most recounts of foquismo, it appears as an exclusive priority: “the city,' Fidel says, 'is a cemetery of revolutionaries and resources" (Debray, 1967: 69). On the contrary, for protracted people's war strategy, building a strong supporting network in the city is a priority, as long as it remains under the political direction of the popular army, implanted in rural territories.

In Argentina, three major organizations identified discursively (and in much more imperfect practical forms) with this strategy. One of them is the PRT after 1968, and more so after 1970 and the creation of the ERP (Carnovale, 2011: 69-120). Another case is the Fuerzas Armadas Revolucionarias (FAR), which originally preferred secret military action to political action directed towards the masses. At the very beginning of the 1970s, individuals willing to join the organization were hence requested to resign any activity in labor unions and student groups, and to dedicate to clandestine military action exclusively. However, starting in 1972, the articulation between the FAR and front organizations was reinforced in the merging with Montoneros (González Canosa, 2012: 187-269). But, in early 1976, Montoneros also evolved towards protracted people's war, with the creation of the Ejército Montonero (Montonero Army), distinct from the Partido Montonero (Montonero Party). The organization's new aim was to build an autonomous military force, distinct from the Peronist movement and able to conduct the revolutionary process on its own (Salas, 2009). This war logic led to the introduction of military ranks, and to the use of uniforms among activists (Salas, 2006b: 18, Gillespie, 2008: 275). The cases of PRT-ERP and Montoneros thus show a 
process of “militarization” (Moyano, 1995, Pozzi, 2004, Calveiro, 2005, Vezzetti, 2009, Bartoletti, 2010a, 2010b, Carnovale, 2011: 92-120) leading to the formal creation of autonomous revolutionary armies. What differentiates these organizations' conception of guerrilla warfare from foquismo? Crucial to the distinction is the explicit rejection of foquismo by revolutionaries themselves: Montoneros even used the concept as a veiled insult to denounce so-called "deviant" tendencies inside the organization (Gillespie, 2008: 144, 400, 417). As for the PRT-ERP, despite claiming to be Guevarist, it clearly privileged Chinese and Vietnamese conceptions of protracted people's war over Cuban-style foquismo (Antognazzi, 1997, Carnovale, 2011: 69-120, Mangiantini, 2012).

Nonetheless, in spite of the declared will to create a proto-regular army, revolutionary groups still put a concrete emphasis on urban guerrilla actions, not on territorial military strategy. In that aspect, Montoneros and the PRT-ERP were part of the broader transnational trend that followed the death of Che Guevara in 1967 (Lamberg, 1971): they did not give up the guerrilla scenario, but they adapted it in many ways. After the 1960s, marked by the spread of rural guerrillas, came the 1970s with the upsurge of urban guerrillas (Ramírez, 2010), theorized by Brazilian Carlos Marighella in 1969 (Marighella, 1970). Compared to foquismo, protracted people's war strategy, based on the articulation between rural and urban spaces, appeared as better suited for this general evolution. Its mixed nature also seems more in line with the organizations' practice: despite sophisticated theoretical ambitions, they basically resorted to an accumulation of disparate actions. Vera Carnovale has indeed noted that, in spite of harsh controversies over strategy, PRT-ERP's activism concretely privileged a catch-all dynamic - combining militant action in the labor unions, urban guerrilla stunts and attempts to create rural guerrilla focos (Carnovale, 2011: 87).

The theory of protracted people's war must therefore be understood as a regulatory ideal rather than as a real organizational construction. What prevailed in the end was the 
conviction (common to protracted people's war and to foquismo) that armed struggle could create the subjective conditions for revolution, and that the intensification of violence and its militarization could accelerate the path to socialism.

\section{Political-Military Strategies}

Political-military organizations (PMOs) were the dominant form of revolutionary organization in the New Left. Their strategy was vague, and did not rely on a specific body of doctrine. Its major aspects can, however, be synthesized as follows: 1) political-military strategy considers armed struggle as a means to awake and strengthen the national and social consciousness of the popular classes; 2) nevertheless, the seizing of power does not rest upon the creation of a popular army but on the articulation of small armed groups' violent action and activism by the masses, especially in labor unions; 3) this articulation does not necessarily lead to unifying armed cells and front organizations: PMOs stimulate popular uprising, but do not always aim at taking its political direction; 4) PMOs' action thus combines military tactics — but without replicating the model of a popular army — and political logics - but without replicating the model of insurrectionist parties. In practice, the action of PMOs mainly consisted in acts of "armed propaganda": armed operations without military objectives, violent actions with symbolic purposes. PMOs thus rested upon a hybrid logic, one of the reasons accounting for the label's diffusion.

Logistical factors also made the choice of PMO strategy a cheaper option than protracted people's war and insurrection. The former implies gathering a large and expensive arsenal: only a minority of organizations could raise enough money to create even an ersatz of popular army. As for the strategy of insurrection, it is also costly in terms of rank and file militancy, for it requires the activation of a dense and nationwide activist network involved in 
labor unions. Comparatively, the action of PMOs requires much more limited financial and human resources. A few activists only are enough to undertake armed actions on symbolic targets, with high levels of public impact, financed with a few robberies or with the theft of a few weapons.

At some point of their organizational trajectory, every Argentine armed group went through a stage during which the role of physical violence was mainly symbolic. Indeed, despite accumulating targeted assassinations, kidnappings and bombings, most armed operations did not mean to dispute the state's control over territory, but to stimulate popular uprising — and also, incidentally, to finance further armed operations through ransom or weapons stealing. As a matter of fact, while it claimed to incarnate a real people's army, most of the PRT-ERP's activities responded to that more modest logic. This is even clearer in the case of Montoneros, which did not formally separate political and military action before 1976 and kept being referred to as "organización politico-militar Montoneros" up until that moment (Salas, 2007, Ramírez, 2010). For instance, by assassinating former dictator Aramburu in 1970, the organization sought to influence politicians and the public, not to gain victory on the military field.

The PMOs' logic appears even more clearly among armed groups that never claimed popular army status. Usually, these organizations were either smaller or more decentralized, a few local groups of armed activists reaching a minimal ideological and strategic consensus but maintaining high levels of operational autonomy. Among previously mentioned organizations, ERP 22 and ERP Fracción Roja were PMOs in the strongest sense (despite the reference to an ejército [army] in their designations), as well as OCPO. We can expand that list to other groups such as the Grupo Obrero Revolucionario (Revolutionary Workers' Group, GOR) (Cortina Orero, 2011) and the Fuerzas Argentinas de Liberación (Argentine Liberation Forces, FAL, also called Fuerzas Armadas de Liberación [Liberation Armed 
Forces] or Frente Argentino de Liberación [Argentine Liberation Front], depending on the period) (Grenat, 2010, Hendler, 2010). After 1968 and the dismantling of their rural guerrilla foco, the FAP also responded to the definition of PMOs, as they focused on armed propaganda and on building connections with the grassroots working classes (through the organization Peronismo de Base) (Antón, 2003).

Argentine New Left organizations can therefore be classified on a horizontal axis representing their instrumental choices, according to the importance given to armed struggle in revolutionary praxis. Rejecting pacifism is a necessary condition to appear on the axis. This can however give birth to different options: insurrectional strategy, political-military organization or protracted people's war theory (from left to right on the axis). Interestingly, the relationship to legal action, and even to electoral participation, is not a relevant criterion to differentiate organizations on the instrumental axis of the Argentine New Left: armed struggle does not prevent from supporting candidates and casting ballots. Consequently, partisans of protracted people's war were not necessarily more hostile to the electoral system than insurrectionists or PMO activists. Often deemed as a "farce", elections could still serve as an instrument of political accumulation among others. On this issue, differences between New Left organizations relied on other criteria, as shown by the Partido Socialista de los Trabajadores (Workers' Socialist Party, PST, former PRT_La Verdad) and the PCR, both insurrectionists. While the PST presented independent candidates in the presidential elections of March and September 1973, the PCR appealed for a blank vote and publicized the slogan "Ni golpe ni elección: revolución" [neither coup d’État, nor election: revolution] (Campione, 2008: 91-92). Similarly, the right side of the instrumental axis welcomed varying views on the matter: while the PRT-ERP did not propose any candidate for the March and September 1973 elections and boycotted the ballots, Montoneros gave full support to Peronist candidates. There is therefore no strict dichotomy between armed struggle and electoral 
turnout. For that matter, the case of ERP 22 is particularly illustrating. This PMO appeared publicly on the $8^{\text {th }}$ of March 1973, when its "commando Eduardo Capello" kidnapped daily newspaper Crónica's director. In exchange for his liberation, it demanded the publication of a platform in the front page, sending its support to the Peronist presidential candidate (“Operación Poniatowski,” 1974, Weisz, 2005: 26). ERP 22 thus publicized its electoral choice through an armed operation, a paradoxical move which shows that these two dimensions of political action were not perceived as incompatible.

\section{Conclusion}

Between 1969 and 1977, the Argentine New Left was a political space delimited by three frontiers and organized in two dimensions. Considering social liberation, national liberation and armed struggle as issues that made sense simultaneously (three frontiers) was a necessary condition to be part of the New Left. Activists then differentiated in ideological terms, opposing Peronism and Marxism, and in instrumental terms, opposing partisans of insurrection, political-military action and war. So far, we have presented these two dimensions of the New Left space separately, but they can also be merged into a single graphical model [see Figure 3], which constitutes a basic map of the Argentine New Left space. This map shows a simplified overview of political cleavages in a complex political reality: it does not ambition to be either complete or indisputable. Rather, it is conceived as a useful approximative device to understand individual and collective trajectories of the Argentine New Left.

The map proves useful to discuss the unity and complexity of the Argentine New Left. There is unity in the New Left space because: 1) in all considered cases, placing each organization on a continuous Marxism/Peronism scale helps understanding their evolution. 
Indeed, while it is generally assumed that understanding the Argentine Left's relation to Peronism is crucial, this is also true for "revolutionary Peronists" as regards Marxism. Actually, none of the considered groups can be easily isolated from the rest. 2) Similar discussions on violence take place both on the Peronist and Marxist sides of the map. The concept of New Left thus provides a useful complement to alternative frames that consider revolutionary actors separately.

Drawing this map is also fruitful to explore the complexity of the Argentine New Left. Our reflection shows that warfare is far from being the only option available among activists, and that popular war itself remains a rather distant perspective when it is formally undertaken. Further, it can be observed that strategic divisions over reform/revolution or institutions/violence do not play a crucial role in differentiating New Left organizations. Partisans of protracted war do not necessarily reject elections, and partisans of insurrection do not value "bourgeois" institutions at all.

More generally, this paper shows that New Left political identities are best understood from a relational point of view. Moving further from separate case studies illustrates how competing actors' attitudes affect ideological and instrumental choices in the New Left space. This relational prism can in turn help understanding how internationally defined ideological postures are recast in specific contexts. Hence Argentine Maoists prefer old-style insurrectionist syndicalism to people's war, embraced by Peronist Montoneros. Following from this, future research should also consider the actual uses of the "New Left" label by activists, to test its subjective congruence with the investigated field. Somehow unexpectedly, mapping the Argentine New Left can thus contribute to de-essentializing our approach to political identities. 
Figure 3: The Space of the Argentine New Left, Bidimensional Representation <FIGURE 3> 


\section{References}

Altamirano, Carlos

2011 Peronismo y cultura de izquierda. Buenos Aires: Siglo Veintiuno

Andújar, Andrea, Débora D’Antonio, and Fernanda Gil Lozano (Eds.)

2009 De minifaldas, militancias y revoluciones: exploraciones sobre los 70 en la Argentina. Buenos Aires: Luxemburg

Antognazzi, Irma

1997 "La lucha armada en la estrategia política del PRT-ERP (1965-1976).” Razón y

Revolución (3). http://revistaryr.org.ar/index.php/RyR/article/view/455 (accessed March $16,2017)$

Antón, Gladys

2003 "La Fuerzas Armadas Peronistas (FAP): los orígenes de la guerrilla peronista y sus debates políticos estratégicos." III Jornadas de Sociología de la Universidad Nacional de La Plata: La Argentina de la crisis. La Plata (Argentina).

http://www.memoria.fahce.unlp.edu.ar/trab_eventos/ev.6837/ev.6837.pdf (accessed March $15,2017)$

Anzorena, Oscar

1998 Tiempo de violencia y utopía: del golpe de Onganía 1966 al golpe de Videla 1976 2nd ed. Buenos Aires: Ediciones del Pensamiento Nacional 
Bartoletti, Julieta

2010 Montoneros: de la movilización a la organización, un caso paradigmático de militarización (PhD). Universidad Nacional de San Martín, San Martín 2010 "Montoneros: interrogantes abiertos casi veinte años después." Studia Politicae (22): $57-95$

Bozza, Juan Alberto Domingo 2001 "El peronismo revolucionario. Itinerario y vertientes de la radicalización, 19591969." Sociohistórica (9-10): 135-169

Calveiro, Pilar

2005 Política y/o violencia: una aproximación a la guerrilla de los años 70. Buenos Aires: Norma

Camelli, Eva

2011 “Montoneros y los 'frentes de masas': el Movimiento Villero Peronista.” IX Jornadas de Sociología. Universidad de Buenos Aires. http://cdsa.aacademica.org/000034/248.pdf (accessed March 16, 2017)

Campione, Daniel 2008 "La izquierda no armada en los años setenta: tres casos, 1973-1976." pp. 85-110 in Clara Lida, Horacio Crespo, and Pablo Yankelevich (eds.), Argentina, 1976: estudios en torno al golpe de Estado. Buenos Aires: Fondo de Cultura Económica 
Campos, Esteban

2012 “"Venceremos en un año o venceremos en diez pero venceremos’: la organización Descamisados: entre la Democracia Cristiana, el peronismo revolucionario y la lucha armada." PolHis (10): 133-145

Carnovale, Vera

2011 Los combatientes: historia del PRT-ERP. Buenos Aires: Siglo Veintiuno

Castro, Dardo and Juan Iturburu

2004 “Organización Comunista Poder Obrero.” Lucha Armada en la Argentina (1): 102109

Celentano, Adrián

2014 "Maoísmo y nueva izquierda: la formación de Vanguardia Comunista y el problema de la construcción del partido revolucionario entre 1965 y 1969.” pp. 83-110 in María Cristina Tortti, Adrián Celentano, and Mauricio Chama (eds.), La nueva izquierda argentina (1955-1976): socialismo, peronismo y revolución. Rosario: Prohistoria

Celesia, Felipe and Pablo Waisberg 2010 Firmenich: la historia jamás contada del jefe montonero. Buenos Aires: Aguilar

Central Intelligence Agency

1977 History of the Montoneros in Argentina from March 1970 to early April 1977 
Chama, Mauricio and Mora González Canosa

2011 "Universidad, política y movimiento estudiantil: la Intervención de Kestelboim y el rol de la Juventud Universitaria Peronista en la Facultad de Derecho de la UBA (19731974)." Conflicto Social (5): 304-333

Che Guevara, Ernesto

1960 La guerra de guerrillas. La Habana: Departamento de instrucción del MINFAR

Coggiola, Osvaldo

2006 Historia del trotskismo en Argentina y América Latina. Buenos Aires: Razón y Revolución

Copello, David

2019 "Faire la révolution par les droits de l'homme : un phénomène d'imbrication militante dans l'Argentine des années 1970 et 1980." Revue Francaise de Science Politique 69 (4): 577-599

2019 "Jacques Vergès, Rupture Strategy and the Argentinean New Left: Circulations and Adaptations of a Judiciary Theory." Global Society 33 (3): 348-364

\section{Cormick, Federico}

2012 Fracción roja: debate y ruptura en el PRT-ERP. Buenos Aires: El Topo Blindado 2015 “Apuntes sobre la Organización Comunista Poder Obrero.” Cuadernos de Marte (8):

$95-128$ 
Cortina Orero, Eudald

2011 Grupo Obrero Revolucionario: autodefensa obrera y guerrilla. Buenos Aires: El Topo Blindado

Cosse, Isabella

2017 ““'Infidelidades”: moral, revolución y sexualidad en las organizaciones de la izquierda armada en la Argentina de los años 70.” Prácticas de oficio 1 (19)

Cucchetti, Humberto

2013 Servir Perón : trajectoires de la Garde de Fer. Rennes: Presses Universitaires de Rennes

De Riz, Liliana

2000 La política en suspenso: 1966-1976. Buenos Aires: Paidós

Debray, Régis

1967 Révolution dans la révolution? Lutte armée et lutte politique en Amérique latine.

Paris: Maspero

Donatello, Luis

2010 Catolicismo y Montoneros: religión, política y desencanto. Buenos Aires: Manantial

Dreyfus-Armand, Geneviève, Robert Frank, Marie-Françoise Lévy, and Michelle ZancariniFournel (Eds.) 
2000 Les années 68 : le temps de la contestation. Paris: Complexe

Duhalde, Eduardo Luis and Eduardo Pérez

2001 De Taco Ralo a la alternativa Independiente: historia documental de las Fuerzas Armadas Peronistas y del Peronismo de Base. Tomo I: Las FAP. La Plata: De la Campana

Ferraro, Vincent

2008 "Dependency theory: an introduction." pp. 58-64 in Giorgi Secondi (ed.), The development economics reader. London: Routledge

Franco, Marina

2012 Un enemigo para la nación: orden interno, violencia y subversión, 1973-1976.

Buenos Aires: Fondo de Cultura Económica

Garaño, Santiago and Werner Pertot

2002 La otra juvenilia: militancia y represión en el Colegio Nacional de Buenos Aires (1971-1986). Buenos Aires: Biblos

Garategaray, Martina

2012 “"Montoneros leales a Perón’: notas sobre la Juventud Peronista Lealtad.”

Naveg@mérica (9). http://revistas.um.es/navegamerica/article/view/162141 (accessed

March 9, 2012)

Gillespie, Richard

1982 Soldiers of Perón: Argentina's Montoneros. Oxford: Clarendon Press 
2008 Soldados de Perón: historia crítica sobre los Montoneros. Buenos Aires:

Sudamericana

González Canosa, Mora

2012 Las Fuerzas Armadas Revolucionarias: orígenes y desarrollo de una particular conjunción entre marxismo, peronismo y lucha armada (1960-1973) (PhD). Universidad Nacional de La Plata, La Plata (Argentina)

Gosse, Van

2005 Rethinking the New Left : an interpretative history. New York: Palgrave Macmillan

Grammático, Karin

2011 Mujeres montoneras: una historia de la Agrupación Evita, 1973-1974. Buenos

Aires: Luxemburg

Grenat, Stella

2010 Una espada sin cabeza: las FAL y la construcción del partido revolucionario en los '70. Buenos Aires: Razón y Revolución

Gutman, Daniel

2003 Tacuara: historia de la primera guerrilla urbana argentina. Buenos Aires: Vergara

Harnecker, Marta

2015 A World to Build: New Paths Toward Twenty-First Century Socialism. New York: NYU Press 
Hendler, Ariel

2010 La guerrilla invisible: historia de las Fuerzas Argentinas de Liberación (FAL).

Buenos Aires: Vergara

Hilb, Claudia and Daniel Lutzky

1984 La nueva izquierda argentina: 1960-1980: política y violencia. Buenos Aires: CEAL

James, Daniel

1976 “The Peronist Left, 1955-1975.” Journal of Latin American Studies 8 (2): 273-296

Keucheyan, Razmig

2012 Hémisphère gauche : une cartographie des nouvelles pensées critiques. Paris: Zones

Lamberg, Roberto

1971 "La guerrilla urbana: condiciones y perspectivas de la 'segunda ola' guerrillera."

Foro Internacional 11 (3): 421-433

Lanusse, Lucas

2005 Montoneros: el mito de sus 12 fundadores. Buenos Aires: Vergara

Lissandrello, Guido

2013 “La izquierda insurreccionalista en la Argentina (1969-1976).” XIV Jornadas

Interescuelas/Departamentos de Historia. Presented at the XIV Jornadas 
Interescuelas/Departamentos de Historia, Universidad Nacional de Cuyo.

http://cdsa.aacademica.org/000-010/589 (accessed March 16, 2017)

\section{Luvecce, Cecilia}

1993 Las Fuerzas Armadas Peronistas y el Peronismo de Base. Buenos Aires: CEAL

Magne, Marcelo Gabriel

2004 Dios está con los pobres: el Movimiento de Sacerdotes para el Tercer Mundo:

prédica revolucionaria y protagonismo social, 1967-1976. Buenos Aires: Imago Mundi

\section{Mangiantini, Martín}

2012 “La polémica Moreno-Santucho: la lucha armada y la ruptura del Partido Revolucionario de los Trabajadores (PRT).” A Contra Corriente 9 (3): 41-66 2014 El trotskismo y el debate en torno a la lucha armada: Moreno, Santucho y la ruptura del PRT. Buenos Aires: El Topo Blindado

Manzano, Valeria

2011 "Cultura, política y movimiento estudiantil secundario en la Argentina de la segunda mitad del siglo XX.” Propuesta Educativa 1 (35): 41-52

2014 The Age of Youth in Argentina: Culture, Politics, and Sexuality from Perón to Videla. Chapell Hill: University of North Carolina Press

Marchesi, Aldo

2017 Latin America's Radical Left: Rebellion and Cold War in the Global 1960s. New York: Cambridge University Press 
2019 "Revolutionaries without Revolution: Regional Experiences in the Forging of a Radical Political Culture in the Southern Cone of South America (1966-1976).” pp. 185211 in Kevin A. Young (ed.), Making the Revolution: Histories of the Latin American Left. New York: Cambridge University Press

Marighella, Carlos

1970 Pour la libération du Brésil. Paris: Seuil

Martín, José Pablo

1992 El Movimiento de Sacerdotes para el Tercer Mundo: un debate argentino. Buenos Aires: Ediciones Castañeda

Marwick, Arthur

1998 The sixties: Cultural revolution in Britain, France, Italy, and the United States, $c$. 1958-c. 1974. Oxford: Oxford University Press

Morello, Gustavo

2003 Cristianismo y revolución: los orígenes intelectuales de la guerrilla argentina.

Córdoba: Universidad Católica de Córdoba

Moyano, María José

1995 Argentina's lost patrol: armed struggle, 1969-1979. New Haven: Yale University Press

Nguyên Giáp, Võ 
1962 People's war, People's Army: the Viet Công insurrection manual for

underdeveloped countries. New York: Praeger

Novaro, Marcos and Vicente Palermo

2003 La dictadura militar, 1976-1983: del golpe de Estado a la restauración democrática.

Buenos Aires: Paidós

Oberti, Alejandra and Roberto Pittaluga

2011 Memorias en montaje: escrituras de la militancia y pensamientos sobre la historia.

Santa Fe: María Muratore

“Operación Poniatowski”

1974, July 27Liberación por la Patria Socialista (22): 11-13

Pozzi, Pablo

2004 Por las sendas argentinas: el PRT-ERP, la guerrilla marxista. Buenos Aires: Imago Mundi

Pozzoni, Mariana

2013 “"Leales' y 'traidores': la experiencia de disidencia de la Juventud Peronista Lealtad (1973-1974)." Nuevo Mundo Mundos Nuevos. http://nuevomundo.revues.org/65393 ; DOI : 10.4000/nuevomundo.65393 (accessed March 9, 2017)

Ramírez, Roberto 
2010 “La repercusión de la Revolución Cubana y la política del ‘foco guerrillero’ en Argentina." História: Debates e Tendências 10 (1): 136-155

Robles, Horacio

2014 "La retaguardia revolucionaria: las unidades básicas controladas por la Juventud Peronista y Montoneros en los barrios populares de la ciudad de La Plata (1972/1975).” pp. 157-188 in María Cristina Tortti, Adrián Celentano, and Mauricio Chama (eds.), La nueva izquierda argentina (1955-1976): socialismo, peronismo y revolución. Rosario:

Prohistoria

Rodríguez, Laura Graciela

2014 "La universidad durante el tercer gobierno peronista (1973-1976)." Conflicto Social 7 (12): $114-145$

Rubenstein, Jérémy

2005 Une histoire du PRT-ERP : depuis ses origines aux “moines rouges” guérilleros (1956-1972) (MA thesis). Université Panthéon Sorbonne, Paris. Retrieved from https://jeremyrubenstein.files.wordpress.com/2011/10/une-histoire-du-prt.pdf

Salas, Ernesto

2006 Uturuncos: el origen de la guerrilla peronista. Buenos Aires: Biblos 2006 “El debate entre Walsh y la conducción Montonera." Lucha Armada en la Argentina (5): 4-19

2007 “El errático rumbo de la vanguardia montonera." Lucha Armada en la Argentina (8): $32-41$ 
2009 "Del foco a la infección: Montoneros y los movimientos sociales." III Jornada Académica "Partidos armados en la Argentina de los setenta." Universidad Nacional de San Martín.

http://www.unsam.edu.ar/escuelas/politica/centro_historia_politica/pdf/foco.pdf (accessed March 16, 2017)

Snitcofsky, Valeria

2014 “Organización territorial y continuidad histórica: aportes a la luz de los congresos nacionales del Movimiento Villero Peronista (1973 y 1974).” Trabajo y sociedad (22): $377-393$

Stavale, Mariela

2012 Las Fuerzas Armadas Peronistas y su experiencia alternativa (1964-1979) (BA thesis). Universidad Nacional de La Plata, La Plata (Argentine). Retrieved from http://www.memoria.fahce.unlp.edu.ar/tesis/te.705/te.705.pdf

Tarcus, Horacio (Ed.)

2007 Diccionario biográfico de la izquierda argentina. Buenos Aires: Emecé

Terán, Oscar

2004 “Lecturas en dos tiempos.” Lucha Armada en la Argentina (1): 12-15

Tortti, María Cristina

1999 “Protesta social y 'Nueva Izquierda' en la Argentina del Gran Acuerdo Nacional.” pp. 205-203 in Alfredo Pucciarelli (ed.), La primacía de la política: Lanusse, Perón y la 
Nueva Izquierda en tiempos del GAN. Buenos Aires: Editorial Universitaria de Buenos Aires

2009 El "viejo" partido socialista y los orígenes de la "nueva” izquierda (1955-1965).

Buenos Aires: Prometeo

Touris, Claudia

2012 Catolicismo y cultura política en la Argentina: la constelación tercermundista (1955-1976) (PhD). Universidad de Buenos Aires, Buenos Aires

Vezzetti, Hugo

2009 Sobre la violencia revolucionaria: memorias y olvidos. Buenos Aires: Siglo

Veintiuno

Weisz, Eduardo

2004 El PRT-ERP: nueva izquierda e izquierda tradicional. Buenos Aires: Centro

Cultural de la Cooperación

2005 “ERP 22 de Agosto: fracción pro Cámpora en el PRT ERP.” Lucha Armada en la Argentina (2): $26-45$

Zanatta, Loris and Mariano Aguas

2005 “Auge y declinación de la tercera posición. Bolivia, Perón y la Guerra Fría, 19431954.” Desarrollo Económico 45 (177): 25-53

Zedong, Mao

1954 On the protracted war. Peking: Foreign Languages Press 
${ }^{1}$ The Cuban model of foquismo was synthesized as follows: "1) Popular forces can win a war against the army.

2) It is not necessary to wait until all conditions for making revolution exist; the insurrection can create them. 3) In underdeveloped America, the countryside is the basic area for armed fighting" (Che Guevara, 1960: 13). 
Fig. 1

Peronism

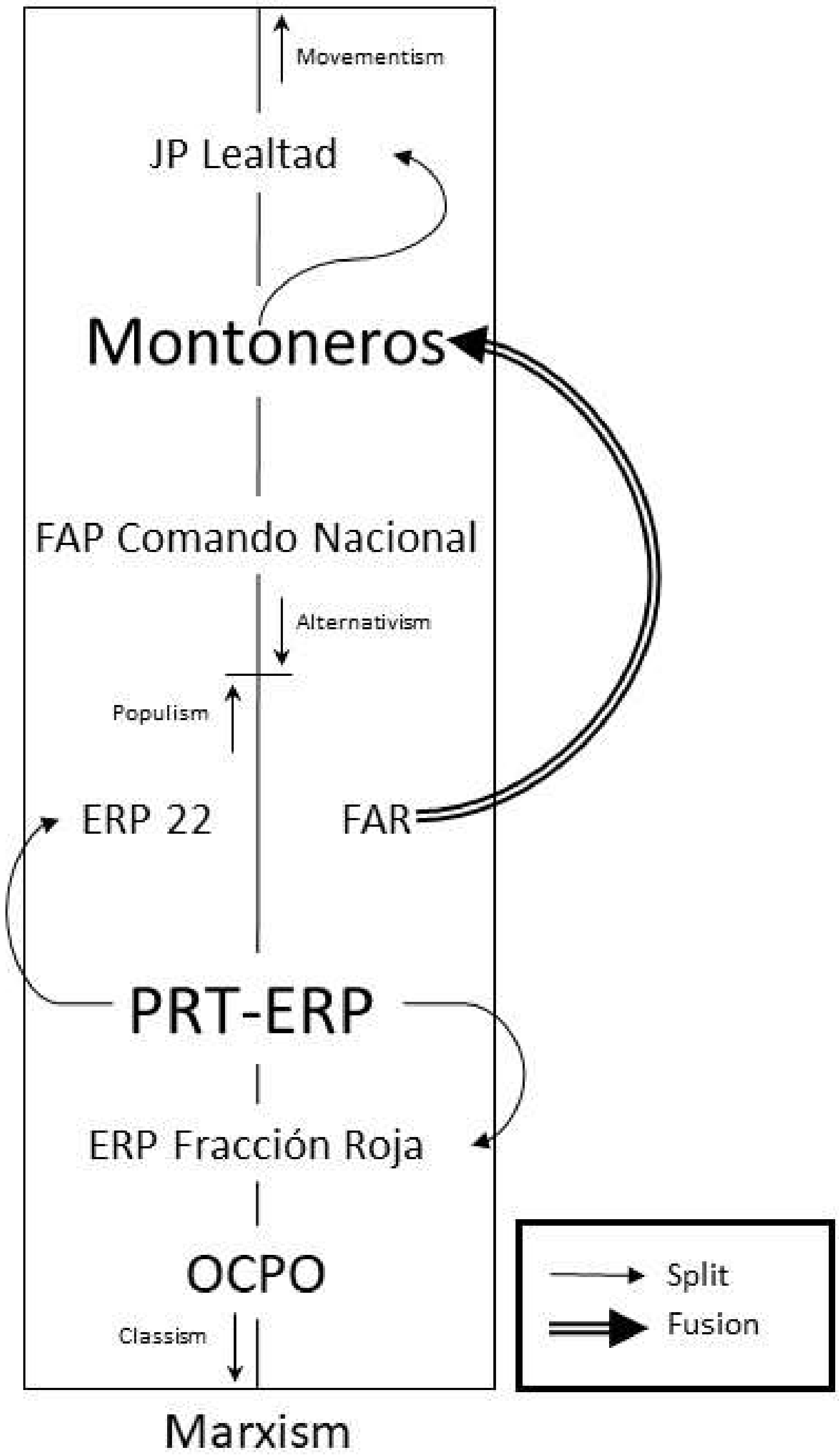


Fig. 2

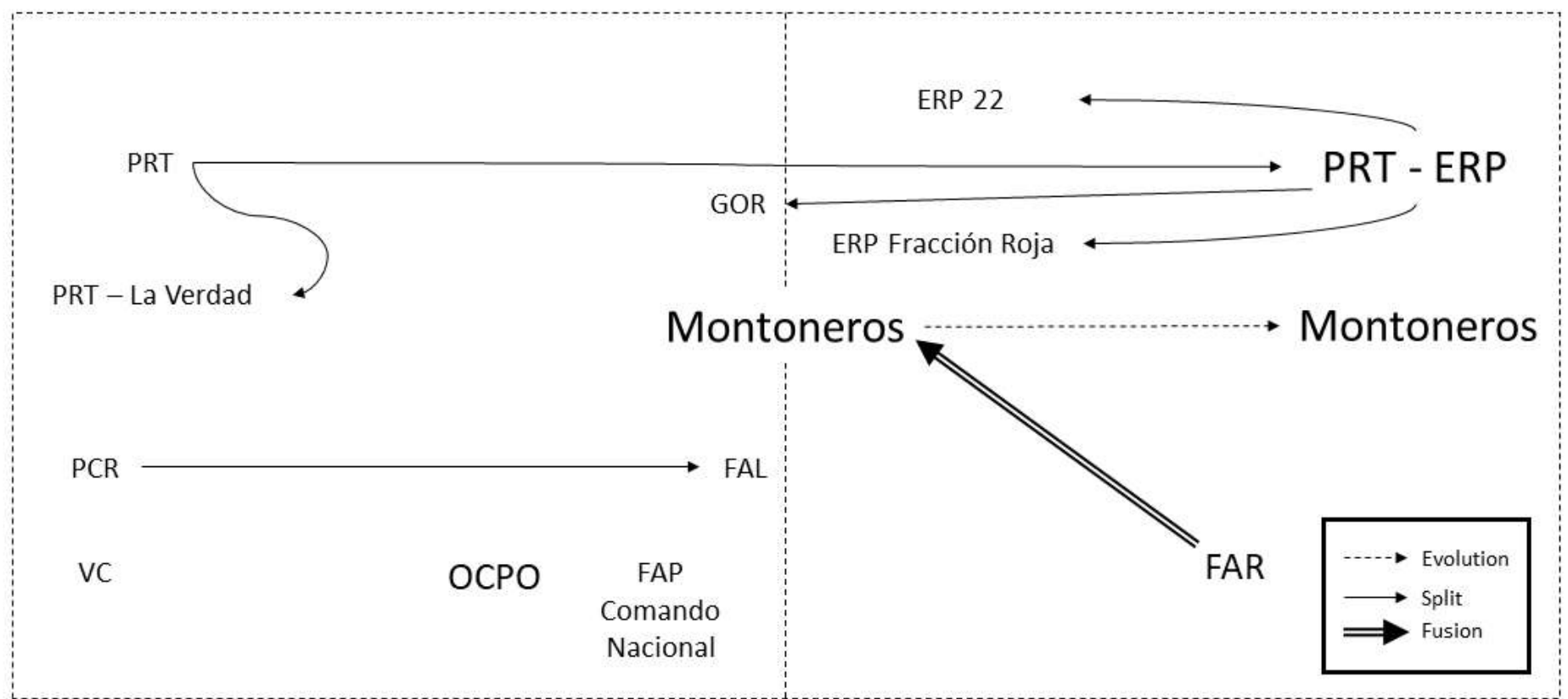

Insurrection

PMO

People's war 
Fig. 3

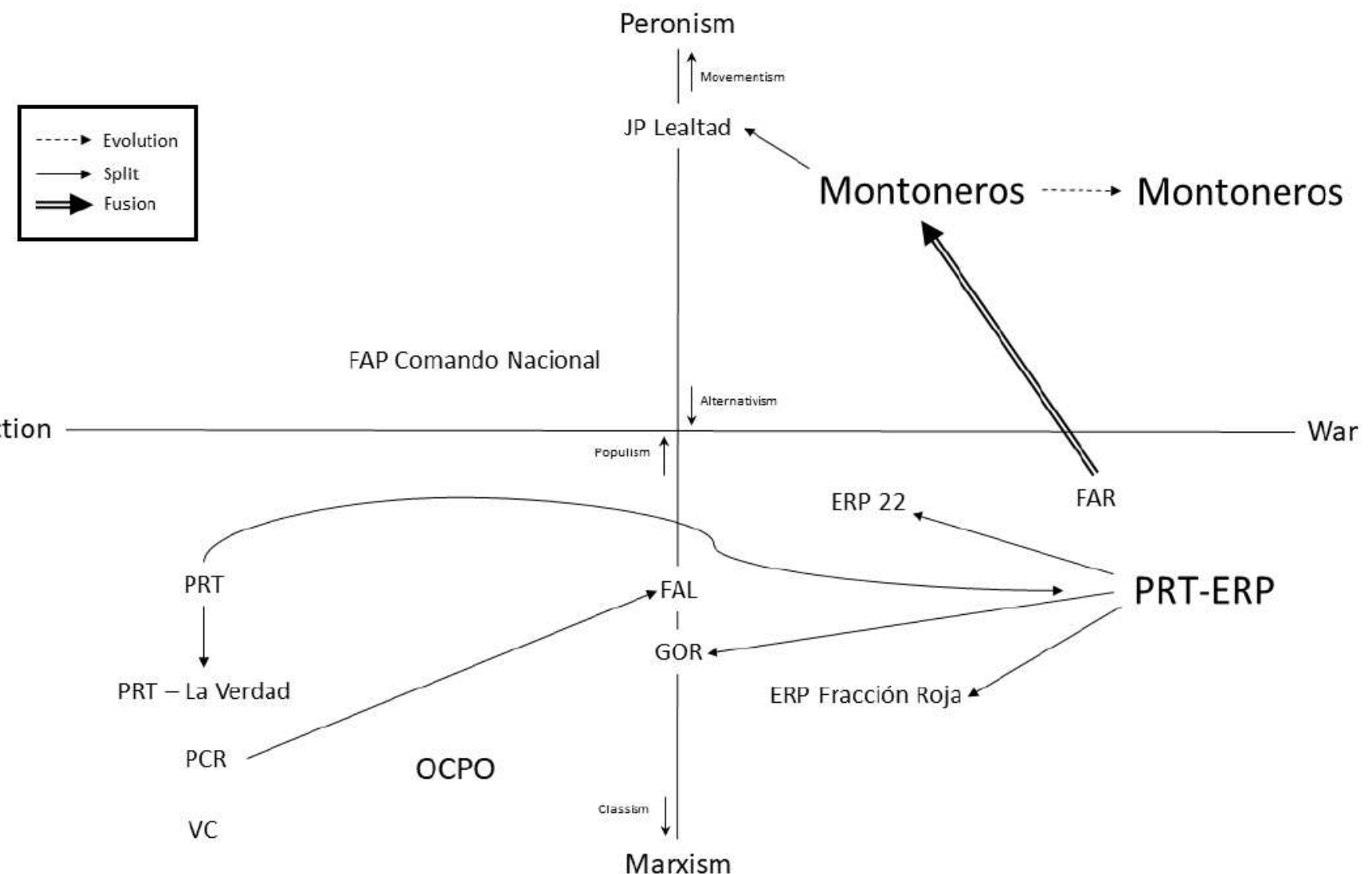

